\title{
RESPONSE OF SOME WHEAT GROWTH TRAITS FOR FOR FOLIAR SPRAYING WITH HUMIC AND GLUTAMIC ACID
}

\author{
H. A. Baqir \\ Lecturer \\ N. H. Zeboon \\ Assist. Prof.
}

Dep. Field crops -Coll. Agric. Engine. Sci. University of Baghdad

\section{ABSTRACT}

E-mail: haderabid@yahoo.com

A field experiment was conducted at the Agricultural Experiment Unit, College of Agriculture Engineering Sciences, University of Baghdad, during two winter seasons 2016-2017 and 20172018 to study the response of some growth traits for wheat $\mathrm{Cv}$. Al forat to foliar spraying using with humic glutamic acid and acid. A factorial experiment was with in Randomized Complete Block Design applied three replications, it involved two factor ,first factor was glutamic acid with three concentrations $(0,250,500) \mathrm{mg} \mathrm{L}^{-1}$, second factor was humic acid with three concentrations $(0,1,2) \mathrm{ml} \mathrm{L}^{-1}$, have been sprayed at tillering and flowering stages. The results showed that all the studed growth traits (plant height, ,number of tillers, flag leaf area dry weight for plant, crop growth rate, relative growth rate and biological yield) were affected by spraying with humic acid and glutamic acid for two season concentration, $2 \mathrm{ml}^{-1}$ from humic acid was superior on most of studies traits, as for glutamic acid,plants treated with concentrations 250 and $500 \mathrm{mg} \mathrm{L}^{-1}$ were produced the highest mean for studies traits but without significant difference between them in some traits .The interaction between two factors was significant on most studies growth traits .

Key words: plant height, tillers, flag leaf area, dry weight for plant, biological yield.

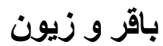

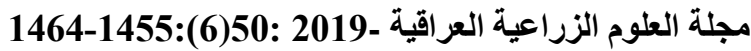

استجابة بعض صفات النمو لمحصول الحنطة للرش الورقي بحامض الهيومك وحامض الكلوتاميك

$$
\text { حيدر عبد الرنلق باقر }
$$

المستخلص

أجريت تجربة حقلية في محطة التجارب الزراعية، كلية علوم الهندة الزراعية- جامعة بغداد خلال الموسمين الثتويين

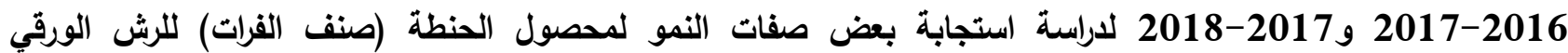
بحامضي الكلوتاميك والهيوميك. طبقت تجرية عاملية على وفق تصميم القطاعات الكاملة المعثاه RCBD بثلاث مكرات،

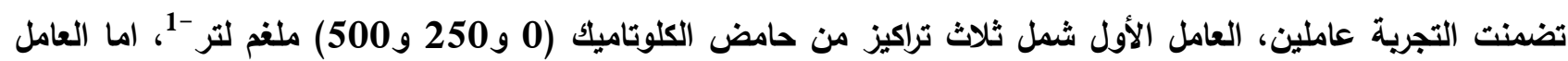
الثاني شمل ثُلاث تراكيز حامض الهيوميك (0 و 1 و2) مل لتر -1 رش الحامضين في مرحلة التفريع والتزهير. أظهرت النتائج ان جميع الصفات المدروسة (ارتفاع النبات وعدد الفروع ومساحة ورقة العلم والوزن الجاف للتبات ومعدل نمو المحصول

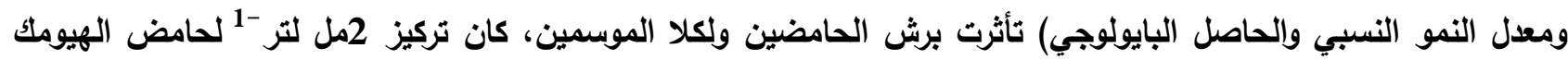

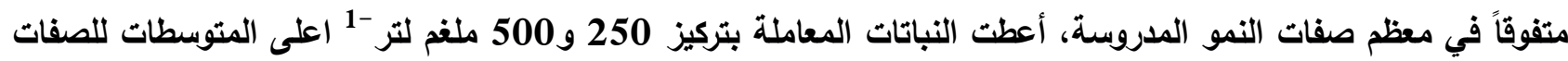
المدروسة دون فرق احصائي بينهما في بعض الصفات. كان التداخل بين العاملين معنوي في معظم صفات النمو المدروسة. الكلمات المفتاحية: ارتفاع النبات، الفروع، مساحة ورقة العلم، الوزن الجاف للنبات، الحاصل البايولوجي مئي 


\section{INTRODUCTION}

Wheat is one of the most important and main crops in Iraq and the world ,a source of energy it content of carbohydrates, proteins and vitamins, its productivity in Iraq still low despite the success factors for its planting, due to many reasons, including the excessive use of fertilizers and in ways that are not studied and which affect on the soil and human health . There are some practices that could be reduce the use of fertilizers which are expensive to a certain level and at the same time its provide plant with essential elements ,such as nitrogen , one of these practices is the use of safe and environmentally friendly materials ,including the use of amino and organic acids ,especially glutamic and humic acid .Humic acid substances are natural technological prouducts with exciting biological effects on crops (10). The importance of humic acid that it activates plant enzymes, It acts as a catalyst in many vital processes that increase plant growth, promot the root length, better absorption of water and nutrients, increase root respiration form root hairs and increase the amino acids ,increase the efficiency of photosynthesis (19) humic acid is also significantly positive effective in leaf chlorophyll content, NPK content in leaves and increase the fresh and dry weight of crop plants, biological yield ,number of flowers ,number of fruits, fruits weight and plant yield $(5,7,8,15,26,27,30)$. Amino acids are found in large amounts in the organism and are built in the mitogundria and plastids to provide the ketonic acids and are a source of energy and encourage vegetative and root growth, adding them increases the duration and number of cellular divisions and expanded (2, 9). Amino acids are not only building blocks of proteins but also basic for a myriad of other molecules that serve important functions in plants, amino acids are involved in the synthesis of other organic compounds such as enzymes, protein, amines, alkaloids ,vitamins ,and plant hormones (11). Glutamic acid is produced from the reaction of $\alpha$ ketoglutaric acid with ammonia in Kreps cycle by the presence of glutamic acid dehydrogenase enzyme and NADP or NAD this reaction is the main implement of the inorganic nitrogen conversion system which is the basic structure of some amino acids such as Arginine and proline which are contribute in protein building and it has an important role in building chlorophyll and carbohydrate formation $(2,14,28)$. The role of amino acids in stimulating growth of several plant species were studied by Sadak et al $(3,6,21,22)$.The aim of this study to know response of some growth and root traits to foliar spry with glutamic acid and humic acid.

\section{MATERIAIS AND METHODS}

A field experiment was conducted at the agricultural experiment unit, College of Agriculture Engineering Sciences, University of Baghdad during the two winter seasons 2016-2017 and 2017-2018 to study the response of some growth traits for wheat (ALForat var.) to foliar spray with glutamic acid and humic acid. A factorial experiment was applied with in randomized complete block design (RCBD) with three replication, it involved two factor ,first factor was glutamic acid with three concentrations $(0,250,500) \mathrm{mg}$ $\mathrm{L}^{-1}$, second factor was humic acid with three concentrations $(0,1,2) \mathrm{ml} \mathrm{L}^{-1}$, It was sprayed at tillering and the beginning of flowering stages, unit area experimental as $(3 \times 2.5) \mathrm{m}^{2}$ with distance $20 \mathrm{~cm}$ between the rows, using, rate of seed $120 \mathrm{~kg} \mathrm{ha}^{-1}$,completed the experience of the fertilizers requirements it was add nitrogen at arte of $200 \mathrm{~kg} \mathrm{ha}^{-1}$ in three stages (tillering, elongation and booting) and the addition of a phosphate fertilizer super phosphate triangular shape at sowing (13) when a plants arrived full flowering stage underwent some measurements:

1. Plant height $(\mathrm{cm})$ : was measured from the base of plant up to spike base of main stem average of ten plants.

2. Total number of tillers, were calculated from the harvested area, $1 \mathrm{~m}^{2}$ for each experimental unit

3. Flag leaf area $\left(\mathrm{cm}^{2}\right)$ ten main flag leaves were Cullum

- Used according to the following equation:

- Flag leaf area $=$ length $\mathrm{x}$ width at middle $\mathrm{x}$ 0.95 (20).

4. Plant dry weight (gm): was calculated for plants in $1 \mathrm{~m} 2$ each experimental unit. Cut its roots to the extent of the coronary region ruled out and put the shoot in paper bag after drying at $65 \mathrm{C}^{\circ}$ degree for 48 hours, samples were 
collected for two-stages elongation (ZGS:31) and $100 \%$ flowering ( ZGS: 69).

5. Crop growth rate (CGR) $\mathrm{gm} \mathrm{m}^{-2} \mathrm{day}^{-1}$. was calculated at ZGS:31- ZGS: 69 using the following equation:

$\mathbf{C G R}=\mathbf{1} / \mathbf{A} \mathbf{w}_{\mathbf{2}}-\mathrm{w}_{\mathbf{1}} / \mathbf{T}_{\mathbf{2}}-\mathbf{T}_{\mathbf{1}}(12)$.

CGR $=$ Crop growth rate

$\mathbf{A}=$ land area occupied by the plant sample $\mathrm{m}^{-}$ 2

$\mathbf{W}_{\mathbf{1}}=$ dry sample weight at $\mathrm{T}_{1}$ (at ZGS: 31 ).

$\mathbf{W}_{\mathbf{2}}=$ dry sample weight at $\mathrm{T}_{2}$ (ZGS: 69).

6. RGR =relative growth rate $\mathrm{gm} \mathrm{gm}^{-1} \mathrm{day}^{-1} \mathrm{It}$ was calculated of the plats sample and the same space above mentioned using the following equation.

$\mathbf{R G R}=\left(\mathbf{I n} \mathbf{W}_{2}-\operatorname{In} \mathbf{W}_{1}\right) / \mathbf{T}_{\mathbf{2}}-\mathbf{T}_{\mathbf{1}}(12)=$

$\mathbf{R G R}=$ Relative growth Rate

In $\mathbf{W}_{\mathbf{1}}=$ a natural logarithm for samples dry weight at $\mathrm{T}_{1}$

In $\mathbf{W}_{\mathbf{2}}=$ a natural logarithm for samples dry weight at $T_{2}$.

7. Biologyical yield: $\mathbf{M g ~ h a}^{-1}$ was measured at full ripening stage

\section{RESUITS AND DISCUSSION}

\section{Plant height}

The data in Table 1 indicate that there was a significant effect of the spraying humic and glutamic acid in plant height for two seasons and the interaction between two factor was significant in the second season only, concentration $2 \mathrm{ml} \mathrm{L}^{-1}$ was superior and gave the highest mean of $93.82 \mathrm{~cm}$ and $95.86 \mathrm{~cm}$ with an increase of $4.66 \%$ and $6.19 \%$ compared with comparison control for two seasons respectively. $2 \mathrm{ml} \mathrm{L}^{-1}$ concentration didn't differ from $1 \mathrm{ml} \mathrm{L}^{-1}$ concentration for two seasons, the reason for the increases in of plant height when spraying with humic acid be due to the role of this acid (hormonal acid as it affects cell protoplasm and cellular wall (23) in increasing the division of cells and their elongation and hence increasing plant height especially that the spraying was in two important stages, tillering and flowering, as the stage of tillering is one of the important stages of wheat crop and characterized by increasing vegetative growth, which is the result of increased cell division .The soms results obtianed from humic acid are in line with those obtained by Khan et al (16) and AL-Curtini and AL-Tai (4) and Zeboon (30).

Table1. Effect of humic acid and glutamic acid on plant height $(\mathrm{cm})$

\begin{tabular}{|c|c|c|c|c|}
\hline \multirow[b]{2}{*}{ Humic acid } & \multicolumn{3}{|c|}{$\begin{array}{c}\text { Season 2016-2017 } \\
\text { Glutamic acid }\end{array}$} & \multirow[b]{2}{*}{ Mean } \\
\hline & 0 & $250 \mathrm{mg} \mathrm{L}^{-1}$ & $500 \mathrm{mg} \mathrm{L}^{-1}$ & \\
\hline \multirow{6}{*}{$\begin{array}{c}0 \\
1 \mathrm{ml} \mathrm{L}^{-1} \\
2 \mathrm{ml} \mathrm{L}^{-1} \\
\text { LSD 0.05 } \\
\text { Mean } \\
\text { LSD 0.05 }\end{array}$} & 85.40 & 91.02 & 92.48 & 89.64 \\
\hline & 89.94 & 93.91 & 96.76 & 93.54 \\
\hline & 90.94 & 97.91 & 92.59 & 93.82 \\
\hline & NS & & & 2.37 \\
\hline & 88.76 & 94.28 & 93.95 & \\
\hline & 2.37 & & & \\
\hline \multirow[b]{2}{*}{ Humic acid } & \multicolumn{3}{|c|}{$\begin{array}{c}\text { Season 2017-2018 } \\
\text { Glutamic acid }\end{array}$} & \\
\hline & $\mathbf{0}$ & $250 \mathrm{mg} \mathrm{L}^{-1}$ & $500 \mathrm{mg} \mathrm{L}^{-1}$ & Mean \\
\hline 0 & 85.94 & 92.70 & 94.22 & 90.27 \\
\hline $1 \mathrm{ml} \mathrm{L}^{-1}$ & 91.02 & 95.20 & 98.61 & 94.94 \\
\hline $2 \mathrm{ml} \mathrm{L}^{-1}$ & 92.15 & 98.61 & 96.15 & 95.86 \\
\hline LSD 0.05 & 2.61 & & & 1.51 \\
\hline Mean & 89.95 & 95.48 & 95.64 & \\
\hline LSD 0.05 & 1.51 & & & \\
\hline
\end{tabular}


The same Table show that the $250 \mathrm{mg} \mathrm{L}^{-1}$ concentration of glutamic acid superior in first season and $500 \mathrm{mg} \mathrm{L}^{-1}$ concentration in second season and produced the hieghst mean of the plant height was $(94.28 \mathrm{~cm}$ and $95.64 \mathrm{~cm})$ without significant difference between two concentrations compared to $88.76 \mathrm{~cm}$ and $89.95 \mathrm{~cm}$ at control treatment (without spraying glutamic) the reason could be due to the role of glutamic acid in plant,one of this ,the amides (of glutamic acid ) induce effects like stimulation of cell wall formation ,elongation of cells and increased cell division (24). This results agreed with the results of Mazher et al (17) Omer et al (18) and Abd allah et al (1). The interaction was significantly in second season only. plant height increase with increasing concentration spray glutamic acid at humic acid concentration itself and reached the maximum heigh of the plant at treatment $\left(250 \mathrm{mg} \mathrm{L}^{-1}+\right.$ $\left.2 \mathrm{ml} \mathrm{L}^{-1}\right)$ and at treatment $\left(500 \mathrm{mgL}^{-1}+1 \mathrm{ml} \mathrm{L}^{-}\right.$

$\left.{ }^{1}\right)$ concentration then got decrease in plant height at $500 \mathrm{mg} \mathrm{L}^{-1}+2 \mathrm{ml} \mathrm{L}^{-1}$ humic acid concentration, but it was not significantly.

Number of tillers $\left(\mathrm{m}^{-2}\right)$

The data in Table 2 show the significant effect, of with amino acid (glutamic) and organic acid (humic acid ) for both season in number of tillers trait, so plant treated with $2 \mathrm{ml} \mathrm{L}^{-1}$ concentration from humic acid which gave higher of number of tillers ( 371.71 and 379.90 tiller plant $^{-1}$ ) as increasing $11.51 \%$ and $10.80 \%$ compared with comparison treatment which gave mean 333.34 and 342.85 tiller plant $^{-1}$ for both seasons respectively. The reason be due to the role of humic acid in plant, it increase the efficiency of photosynthesis and also significantly positive effective in leaf chlorophyll content (19) and this reflected on growth of plant develop of tillers.

Table 2. Effect of humic acid and glutamic acid on number of tillers $\mathbf{m}^{-2}$

\begin{tabular}{|c|c|c|c|c|}
\hline \multirow[b]{2}{*}{$\begin{array}{c}\text { Humic acid } \\
0 \\
1 \mathrm{ml} \mathrm{L}^{-1} \\
2 \mathrm{ml} \mathrm{L}^{-1} \\
\text { LSD 0.05 } \\
\text { Mean } \\
\text { LSD 0.05 }\end{array}$} & \multicolumn{3}{|c|}{$\begin{array}{c}\text { Season 2016-2017 } \\
\text { Glutamic acid }\end{array}$} & Mean \\
\hline & $\begin{array}{c}268.91 \\
303.26 \\
330.25 \\
19.69 \\
300.81 \\
11.37\end{array}$ & \begin{tabular}{l|}
344.85 \\
366.48 \\
389.19
\end{tabular} & $\begin{array}{l}386.25 \\
403.77 \\
395.69\end{array}$ & $\begin{array}{c}333.34 \\
357.84 \\
371.71 \\
11.37\end{array}$ \\
\hline Humic acid & $\mathbf{0}$ & $\begin{array}{c}\text { Season } 2017 \\
\text { Glutamic } \\
250 \mathrm{mg} \mathrm{L}^{-1}\end{array}$ & $500 \mathrm{mg} \mathrm{L}^{-1}$ & Mean \\
\hline $\begin{array}{c}0 \\
1 \mathrm{ml} \mathrm{L}^{-1} \\
2 \mathrm{ml} \mathrm{L}^{-1} \\
\text { LSD 0.05 } \\
\text { Mean } \\
\text { LSD 0.05 }\end{array}$ & $\begin{array}{c}281.98 \\
319.81 \\
352.79 \\
15.84 \\
318.19 \\
9.14\end{array}$ & $\begin{array}{l}366.08 \\
384.05 \\
396.79\end{array}$ & $\begin{array}{l}380.51 \\
414.93 \\
390.13\end{array}$ & $\begin{array}{c}342.85 \\
372.93 \\
379.90 \\
9.14\end{array}$ \\
\hline
\end{tabular}

The same Table show that the concentration $500 \mathrm{mg} \mathrm{L}^{-1}$ of glutamic acid was significant effect and superior with high mean (395.24 and 395.19) tiller plant ${ }^{-1}$ compared with treatment compared and $250 \mathrm{mg} \mathrm{L}^{-1}$ concentration, which gave 300.81 and 366.84 tiller plant ${ }^{-1}$ for first season and 318.19 and 382.31 tiller plant $^{-1}$ for second season with significantly differences. The reason could be due to the role of glutamic acid, ability to release substances similar to plant hormones that utilize elements and nutrients to increase plant uptake and growth (25), this results agreed with the results of other researcher (17) and (6). The interaction between two factors was significantly effect in this trait for two seasons, Response of this trait was different with concentrations different, Number of tillers were increased by increasing of humic spray concentration at the same concentrations of glutamic acid (0 and 250$) \mathrm{mgL}^{-1}$ while at $500 \mathrm{mg} \mathrm{L}^{-1}$ concentration the increasing in number of tillers to $2 \mathrm{ml} \mathrm{L}^{-1}$ concentration as decreased in this trait, another words at high 
concentration from humic acid and glutamic acid decrease in this trait.

Flag Leaf area $\left(\mathrm{cm}^{2}\right)$

The data in Table 3 indicate flag leaf area effected by foliar spraying with humic acid and glutamic acid for two seasons and the interaction between them in second season only, from the some Table show increasing flag leaf area with increasing of humic acid concentrations from 0 to $2 \mathrm{ml} \mathrm{L}^{-1}$ The high mean at $2 \mathrm{ml} \mathrm{L}^{-1}$ concentration was $43.67 \mathrm{~cm}^{2}$ and $45.56 \mathrm{~cm}^{2}$ for two season as increasing
$14.08 \%$ and $12.13 \%$ compared with comparison treatment for two season, this increasing could by due to the role of humic acid in increasing bioactivity for plant including uptake elements nutrias and act enzymatic activation and increase for production in addition increase chlorophyll development and sugars and amino acid and contribute to raise the efficiency of photosynthesis and the increase plant growth (leaf area ) (19).

Table 3. Effect of humic acid and glutamic acid on Flag Leaf area $\left(\mathrm{cm}^{2}\right)$

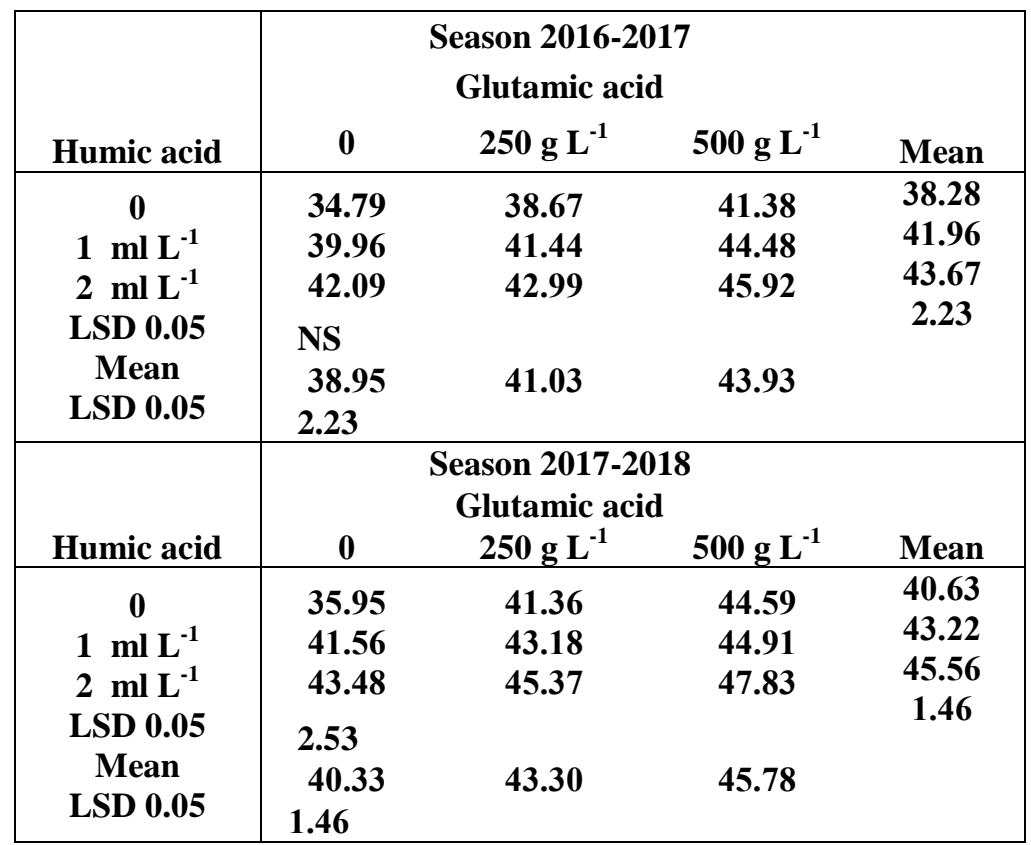

The same Table show $500 \quad \mathrm{mg} \mathrm{L}^{-1}$ concentration was superior in this trait it gave high of mean was (43.93 and $45.78 \mathrm{~cm}^{2}$ compared with comparison treatment and 250 $\mathrm{mg} \mathrm{L}^{-1}$ concentration which gave $38.95,41.03$, 40.33 and $43.30 \mathrm{~cm}^{2}$ for two season respectively.The reason could be due to the ability of glutamic acid to release substances similar to plant hormones that utilize nutrients and increase their uptake for plant growth (25). These results agreed with (6). The same table show that the interaction between two factor was significantly for second season only, So we show the increase in glutamic acid concentration the flag leaf area was significantly higher in the same concentrations of humic acid but this increase was higer at without spraying with humic acid than the spray with humic acid, with 1 and $2 \mathrm{ml} \mathrm{L}^{-1}$ concentration was $24.03 \%$ compared with nonglutamic acid spray treatment, the combination
$500 \mathrm{mg} \mathrm{L}^{1}$ concentration from glutamic acid and $2 \mathrm{ml} \mathrm{L}^{-1}$ concentrations from humic acid gave maximum average for flag leaf area was $47.83 \mathrm{~cm}^{2}$.

\section{Dry weight for plant (gm m)}

The data in table 4 show the significant effect for spraying with glutamic and humic acid on increasing of plant dry weight at elongation and flowering stages, So $1 \mathrm{ml} \quad \mathrm{L}^{-1}$ concentration from humic acid was superior in this trait and for two stage on first season and for $100 \%$ flowering stage in second season while $2 \mathrm{ml} \mathrm{L}^{-1}$ concentration was superior in elongation stage in second season, $1 \mathrm{ml} \mathrm{L}^{-1}$ and $2 \mathrm{mlL}$ concentration didn't significant different between them in elongation stage and they gave mean $75.66 \mathrm{gm} \mathrm{m}^{-2}$ and $79.09 \mathrm{gm} \mathrm{m}$ -2 compared with 72.06 and $75.43 \mathrm{gm} \mathrm{m}^{-2}$ at comparison treatment and for two season respectively, either at flowering stage the $1 \mathrm{ml}$ $\mathrm{L}^{-1}$ concentration gave highest of mean was 
$1274.40 \mathrm{gm} \mathrm{m}^{-2}$ and $1320.35 \mathrm{gm} \mathrm{m}^{-2}$ by increasing was $(17.55 \%$ and $15.40 \%)$ at comparison treatment and for two seasons respectively .Perhaps this reason for that humic acid spray at tillering stage which considered the important stage from wheat growth stages which is determined by number of spikes ,so the plant needed to nutrients in this stage and the humic acid act un increasing the biological activates for plant and increasing cells division and their increasing number of tillers, could be this concentration is sufficient to this increase so that didn't exist in induce this response to high concentrations $\left(2 \mathrm{ml} \mathrm{L}^{-1}\right)$ at first season and low response at second season and then led to increasing number of tillers concentration consequence (increasing shoot) to $100 \%$ flowering .This results agreed with $(26,30)$. Plant dry weight was increased at elongation stage with increasing glutamic acid concentration and reached high mean for dry weight at $500 \mathrm{mg} \mathrm{L}^{-}$ 1 concentration without significant differ with $250 \mathrm{mg} \mathrm{L}^{-1}$ concentration compared with control (comparison) treatment (sprayed with water) was $71.45 \mathrm{gm} \mathrm{m}^{-2}$ and $73.28 \mathrm{gm} \mathrm{m}^{-2}$ for two season respectively, ether at $100 \%$ flowering stage $250 \mathrm{mg} \mathrm{L}^{-1}$ concentration was superior by gave high mean of dry weight was $1284.03 \mathrm{gm} \mathrm{m}^{-2}$ and $1337.17 \mathrm{gm} \mathrm{m}^{-2}$ as increasing $21.57 \%$ and $22.44 \%$ at comparison treatment the reason of this could be back to the spraying glutamic acid at this stages (tillering and flowering) led to increasing plant shoot and then to increasing dry weight, response of plant for spraying with glutamic acid concentration at the beginning of flowering stage was low for high concentration (500 mg L $\mathrm{m}^{-1}$ ) and the low concentration (250 $\mathrm{mg} \mathrm{L}^{-1}$ ) may induced the response in plant and was effected on increasing of dry weight for plant, this result agreed with $(6,7)$ As for the interaction between factor was significantly in this trait and for two stages and for two season we note at without glutamic spray get an increase in dry weight at humic acid spray concentration increasing, either at $250 \mathrm{mg} \mathrm{L}^{-1}$ and $500 \mathrm{mg} \mathrm{L}^{-1}$ concentration the dry weight was increased with humic concentration increasing from o to $1 \mathrm{ml} \mathrm{L}^{-1}$ ether at $2 \mathrm{ml} \mathrm{L}^{-2}$ concentration this trait was decreased but it is no significant at elongation stage and $100 \%$ flowering stage at $250 \mathrm{mg} \mathrm{L}^{-1}$ concentration glutamic acid for two season and significant at $500 \mathrm{mg} \mathrm{L}^{-1}$ concentration at $100 \%$ flowering and seasons that is to mean at high concentration from humic acid $\left(2 \mathrm{ml} \mathrm{L}^{-1}\right)$ no response for plant with the same concentration $250 \mathrm{mg} \mathrm{L}^{-1}$ and $500 \mathrm{mg} \mathrm{L}^{-1}$ rom glutamic acid.

Table 4. Effect of humic acid and glutamic acid on dry weight for plant gm $\mathbf{m}$

\begin{tabular}{|c|c|c|c|c|c|c|c|c|}
\hline \multirow[b]{2}{*}{ Humic acid } & \multicolumn{3}{|c|}{$\begin{array}{c}\text { Season 2016-2017 } \\
\text { Stage elongation } \\
\text { Glutamic acid }\end{array}$} & \multirow[b]{2}{*}{ Mean } & \multicolumn{3}{|c|}{$\begin{array}{c}\text { Season 2016-2017 } \\
\text { Stage flowering } \\
\text { Glutamic acid }\end{array}$} & \multirow[b]{2}{*}{ Mean } \\
\hline & $\mathbf{0}$ & $250 \mathrm{mg} \mathrm{L}^{-1}$ & $500 \mathrm{mg} \mathrm{L}^{-1}$ & & $\mathbf{0}$ & $250 \mathrm{mg} \mathrm{L}^{-1}$ & $500 \mathrm{~m} \mathrm{~g} \mathrm{~L}^{-1}$ & \\
\hline $\mathbf{0}$ & 69.59 & 73.76 & 72.83 & 72.06 & 992.83 & 1193.69 & 1066.83 & 1084.12 \\
\hline $1 \mathrm{ml} \mathrm{L}^{-1}$ & 70.60 & 77.90 & 78.48 & 75.66 & 1078.15 & 1375.78 & 1369.27 & 1274.40 \\
\hline $2 \mathrm{ml} \mathrm{L}^{-1}$ & 74.15 & 75.47 & 76.01 & 75.21 & 1097.41 & 1283.63 & 1144.86 & 1175.30 \\
\hline LSD 0.05 & 2.76 & & & 1.59 & 112.02 & & & 64.67 \\
\hline $\begin{array}{c}\text { Mean } \\
\text { LSD } 0.05\end{array}$ & $\begin{array}{l}71.45 \\
1.59\end{array}$ & 75.71 & 75.77 & & $\begin{array}{c}1056.13 \\
64.67\end{array}$ & 1284.03 & 1193.66 & \\
\hline \multirow[b]{2}{*}{ Humic acid } & \multicolumn{3}{|c|}{$\begin{array}{c}\text { Season 2017-2018 } \\
\text { Stage elongation } \\
\text { Glutamic acid }\end{array}$} & & \multicolumn{3}{|c|}{$\begin{array}{l}\text { Season 2017-2018 } \\
\text { Stage flowering } \\
\text { Glutamic acid }\end{array}$} & \\
\hline & $\mathbf{0}$ & $250 \mathrm{mg} \mathrm{L}^{-1}$ & $500 \mathrm{mg} \mathrm{L}^{-1}$ & Mean & $\mathbf{0}$ & $250 \mathrm{mg} \mathrm{L}^{-1}$ & $500 \mathrm{mg} \mathrm{L}^{-1}$ & Mean \\
\hline 0 & 69.88 & 78.18 & 78.57 & 75.43 & 999.25 & 1280.44 & 1157.62 & 1144.10 \\
\hline $1 \mathrm{ml} \mathrm{L}^{-1}$ & 72.51 & 80.24 & 81.64 & 78.13 & 1129.24 & 1404.11 & 1427.71 & 1320.35 \\
\hline $2 \mathrm{ml} \mathrm{L}^{-1}$ & 75.46 & 79.65 & 80.16 & 79.09 & 1152.68 & 1326.94 & 1231.45 & 1237.02 \\
\hline LSD 0.05 & 2.20 & & & 1.27 & 93.04 & & & 53.72 \\
\hline Mean & 73.28 & 79.36 & 80.01 & & 1092.06 & 1337.17 & 1272.26 & \\
\hline LSD 0.05 & 1.27 & & & & 53.72 & & & \\
\hline
\end{tabular}

Crop growth rate $\left(\mathrm{gm} \mathrm{m}^{-2}\right.$ day $\left.^{-1}\right)$

The data in Table 5 shows that crop growth rate was significant effected from elongation to flowering duration (ZGS: 31- ZGS:69) by glutamic and humic spraying, the Table shows that $1 \mathrm{ml} \mathrm{L}^{-1}$ was superiored in this trait by the 
sprayed plant higher of mean for this trait (20.32 and $21.05 \mathrm{gm} \mathrm{m}^{-2} \mathrm{day}^{-1}$ ) for two season respectively compared with comparison treatment which recorded low mean (17.16 and $18.11 \mathrm{gm} \mathrm{m}^{-2}$ day $^{-1)}$ for two season respectively. the reason could be due to the superior this concentration on increasing dry weight at elongation stage and $100 \%$ flowering (Table 4) and reflected this on increasing crop growth rate. The concentration of glutamic (250) $\mathrm{mg} \mathrm{L}^{-1}$ was superior in this trait gave higher of mean (20.48 and $21.32 \mathrm{gm} \mathrm{m}^{-2}$ day $^{-1}$ ) increasing was $22.70 \%$ and $23.45 \%$ compared with comparison treatment (without sprayed) the reason may be due to that $250 \mathrm{mg} \mathrm{L}^{-1}$ concentration didn't significant differed with $500 \mathrm{mg} \mathrm{L}^{-1}$ concentration in increasing dry weight for plant at elongation stage (Table 4) and $250 \mathrm{mg} \mathrm{L}^{-1}$ concentration was superior at $100 \%$ flowering stage by plant sprayed by this concentration has higher of mean for dry weight (Table 4) and then reflected on increasing crop growth rate for ZGS:31ZGS:69 duration. As for interaction between two factor was significantly effect in this trait ,so crop growth rate increased at without glutamic spray with increasing humic concentration either at $250,500 \mathrm{mg} \mathrm{L}^{-1}$ concentration this trait increasing and reached high mean at $1 \mathrm{ml} \mathrm{L}^{-1}$ concentration from humic acid and at 250 and $500 \mathrm{mg} \mathrm{L}^{-1}$ glutamic acid concentration and then decreased this trait at $2 \mathrm{ml} \mathrm{L}^{-1}$ concentration from humic acid for two seasons, another words higher of mean for crop growth rate for ZGS:31-ZGS:69 duration as a measure of Zadoks et al (29). was at $250 \mathrm{mg} \mathrm{L}^{-1}$ concentration and $1 \mathrm{mlL}$ for first season and $500 \mathrm{mg} \mathrm{L}^{-1}+1 \mathrm{ml} \mathrm{L}^{-1}$ from humic acid for second season without significant different between them for two seasons.

Table 5. Effect of humic acid and glutamic acid on crop growth rate $\left(\mathrm{gm} \mathrm{m}^{-2} \mathrm{day}^{-1}\right)$ for ZGS: 31-ZGS: 69

\begin{tabular}{|c|c|c|c|c|}
\hline \multirow[b]{2}{*}{ Humic acid } & \multicolumn{3}{|c|}{$\begin{array}{l}\text { Season 2016-2017 } \\
\text { Glutamic acid }\end{array}$} & \multirow[b]{2}{*}{ Mean } \\
\hline & $\mathbf{0}$ & $250 \mathrm{mg} \mathrm{L}^{-1}$ & $500 \mathrm{mg} \mathrm{L}^{-1}$ & \\
\hline \multirow{6}{*}{$\begin{array}{c}0 \\
1 \mathrm{ml} \mathrm{L}^{-1} \\
2 \mathrm{ml} \mathrm{L}^{-1} \\
\text { LSD 0.05 } \\
\text { Mean } \\
\text { LSD 0.05 }\end{array}$} & 15.65 & 18.97 & 16.85 & \multirow{6}{*}{$\begin{array}{c}17.16 \\
20.32 \\
18.64 \\
1.09\end{array}$} \\
\hline & 17.08 & 22.00 & 21.88 & \\
\hline & 17.34 & 20.48 & 18.11 & \\
\hline & 1.89 & \multirow{3}{*}{20.48} & \multirow{3}{*}{18.95} & \\
\hline & 16.69 & & & \\
\hline & 1.09 & & & \\
\hline \multirow[b]{2}{*}{ Humic acid } & \multicolumn{3}{|c|}{$\begin{array}{c}\text { Season 2017-2018 } \\
\text { Glutamic acid }\end{array}$} & \multirow[b]{2}{*}{ Mean } \\
\hline & $\mathbf{0}$ & $250 \mathrm{mg} \mathrm{L}^{-1}$ & $500 \mathrm{mg} \mathrm{L}^{-1}$ & \\
\hline \multirow{6}{*}{$\begin{array}{c}0 \\
1 \mathrm{ml} \mathrm{L}^{-1} \\
2 \mathrm{ml} \mathrm{L}^{-1} \\
\text { LSD 0.05 } \\
\text { Mean } \\
\text { LSD 0.05 }\end{array}$} & 15.67 & 20.38 & 18.29 & \multirow{6}{*}{$\begin{array}{c}18.11 \\
21.05 \\
19.63 \\
0.91\end{array}$} \\
\hline & 17.91 & 22.44 & 22.81 & \\
\hline & 18.22 & 21.14 & 19.51 & \\
\hline & 1.57 & & & \\
\hline & 17.27 & 21.32 & 20.21 & \\
\hline & 0.91 & & & \\
\hline
\end{tabular}

\section{Relative growth rate $\left(\mathrm{gm} \mathrm{gm}^{-1} \mathrm{day}^{-1}\right)$}

From the data in Table 6 we note the significant effect of glutamic acid and humic acid spray in increasing relative growth rate for two seasons ,so $1 \mathrm{mlL}$ concentration was superior for two season in ZGS:31-ZCS: 69 duration. The plants which sprayed by this concentration $\left(1 \mathrm{ml} \mathrm{L}^{-1}\right)$ has higher mean of this trait and gave the same mean was 0.0478 $\mathrm{gm} \mathrm{gm}^{-1}$ day $^{-1}$ compared with comparison treatment which gave low of mean was
$0.0459 \mathrm{gm} \mathrm{gm}^{-1} \mathrm{day}^{-1}$ and $0.0460 \mathrm{gm} \mathrm{gm}^{-1}$ day 1 , the reason of this could be due to the plants which sprayed by this concentration had high mean of crop growth rate in the same duration (ZGS:31 - ZGS:69) (Table 5) and reflected this increasing of relative growth rate by significant differ with $2 \mathrm{ml} \mathrm{L}^{-1}$ concentration Sprayed treatment with $250 \mathrm{mg} \mathrm{L}^{-1}$ glutamic acid was significant in this trait by gave high of mean for relative growth rate was 0.0479 and $0.0478 \mathrm{gm} \mathrm{gm}^{-1} \mathrm{day}^{-1}$ for two season 
respectively with significant differ about 500 $\mathrm{mg} \mathrm{L}^{-1}$ concentration the reason of this could be due to the plants which sprayed by this concentration $\left(250 \mathrm{mg} \mathrm{L}^{-1}\right)$ has high mean of crop growth rate in the same duration (ZGS:31
- ZGS:69 ) (Table 5) and reflected this increasing of relative growth rate .The interaction between two factor was note significantly effects in this trait.

Table 6. Effect of humic acid and glutamic acid on relative growth rate $\left(\mathrm{gm} \mathrm{gm}^{-1} \mathrm{day}^{-1}\right)$

\begin{tabular}{|c|c|c|c|c|}
\hline \multirow[b]{2}{*}{ Humic acid } & \multicolumn{3}{|c|}{$\begin{array}{l}\text { Season 2016-2017 } \\
\text { Glutamic acid }\end{array}$} & \multirow[b]{2}{*}{ Mean } \\
\hline & $\mathbf{0}$ & $250 \mathrm{mg} \mathrm{L}^{-1}$ & $500 \mathrm{mg} \mathrm{L}^{-1}$ & \\
\hline \multirow{5}{*}{$\begin{array}{c}\mathbf{0} \\
1 \mathrm{ml} \mathrm{L}^{-1} \\
2 \mathrm{ml} \mathrm{L}^{-1} \\
\text { LSD 0.05 } \\
\text { Mean } \\
\text { LSD 0.05 }\end{array}$} & 0.0450 & 0.0472 & 0.0455 & 0.0459 \\
\hline & 0.0462 & 0.0487 & 0.0484 & 0.0478 \\
\hline & 0.0456 & 0.0480 & 0.0459 & 0.0465 \\
\hline & & & & 0.0009 \\
\hline & $\begin{array}{c}0.0456 \\
0.0009\end{array}$ & 0.0479 & 0.0466 & \\
\hline \multirow[b]{2}{*}{ Humic acid } & \multicolumn{3}{|c|}{$\begin{array}{l}\text { Season 2017-2018 } \\
\text { Glutamic acid }\end{array}$} & \\
\hline & 0 & $250 \mathrm{mg} \mathrm{L}^{-1}$ & $500 \mathrm{mg} \mathrm{L}^{-1}$ & Mean \\
\hline \multirow{6}{*}{$\begin{array}{c}\mathbf{0} \\
1 \mathrm{ml} \mathrm{L}^{-1} \\
2 \mathrm{ml} \mathrm{L}^{-1} \\
\text { LSD 0.05 } \\
\text { Mean } \\
\text { LSD 0.05 }\end{array}$} & 0.0450 & 0.0474 & 0.0457 & 0.0460 \\
\hline & $\begin{array}{l}0.04+0465 \\
0.045\end{array}$ & $\begin{array}{l}0.04+74 \\
0.0485\end{array}$ & 0.0485 & 0.0478 \\
\hline & 0.0458 & 0.0477 & 0.0463 & 0.0466 \\
\hline & & & & 0.0007 \\
\hline & 0.0458 & 0.0478 & 0.0468 & \\
\hline & 0.0007 & & & \\
\hline
\end{tabular}

\section{Biological yield ( $\mathrm{Mg} \mathrm{ha}^{-1}$ )}

The data in Table 7 shows presence significant difference in biological yield for plant by effect of spraying with glutamic and humic acid and interaction between them,$\left(2 \mathrm{ml} \mathrm{L}^{-1}\right.$ concentration), was superior by recorded higher of mean for this trait was 12.80 and $13.25 \mathrm{Mg} \mathrm{ha}^{-1}$ compared with 11.80 and 12.54 $\mathrm{Mg} \mathrm{ha}^{-1}$ for first season and 12.58 and 13.07 $\mathrm{Mg} \mathrm{ha}{ }^{-1}$ for second season respectively comparison without spraying and spray with $1 \mathrm{mlL}$ concentration from humic acid, the reason may be due to the plants were treated by $2 \mathrm{ml} \mathrm{L}^{-1}$ concentration has higher of mean of plant high (Table 1) and high of number of tillers (table 2) which led to increasing dry weight and led to biological yield ,this result agreed with Tufail et al (2014) and Zeboon (30). $500 \mathrm{mg} \mathrm{L}^{-1}$ concentration was superior by gave higher of mean for this trait was 12.97 and $13.45 \mathrm{Mg} \mathrm{ha}^{-1}$ without significant differ with $250 \mathrm{mg} \mathrm{L}^{-1}$ for two season respectively, the proportion of the increase with control treatment was $14.45 \%$ and $11.99 \%$ for two seasons respectively. The reason could be due to superior of $500 \mathrm{mg} \mathrm{L}^{-1}$ concentration in number of tillers (Table 2) and then reflected on increasing dry weight for plant (table 4) and then increasing biological yield. The interaction between two factor in this trait was significant, so biological yield increase with increaseing of humic acid concentration at 0 and $250 \mathrm{mg} \mathrm{L}$ concentration from glutamic acid, while at $500 \mathrm{mg} \mathrm{L}^{-1}$ concentration got this increasing but it decreased at $2 \mathrm{ml} \mathrm{L}^{-1}$ concentration from humic acid but it (decreased ) was not significant and higher of biological yield was $13.47 \mathrm{Mg} \mathrm{ha}^{-1}$ at $2 \mathrm{ml} \mathrm{L}^{-1}$ humic acid $+250 \mathrm{mg} \mathrm{L}^{-1}$ glutamic acid in first season and $14.13 \mathrm{Mg} \mathrm{ha}^{-1}$ in second season. 
Table 7. Effect of humic acid and glutamic acid on biological yield Mg ha ${ }^{-1}$

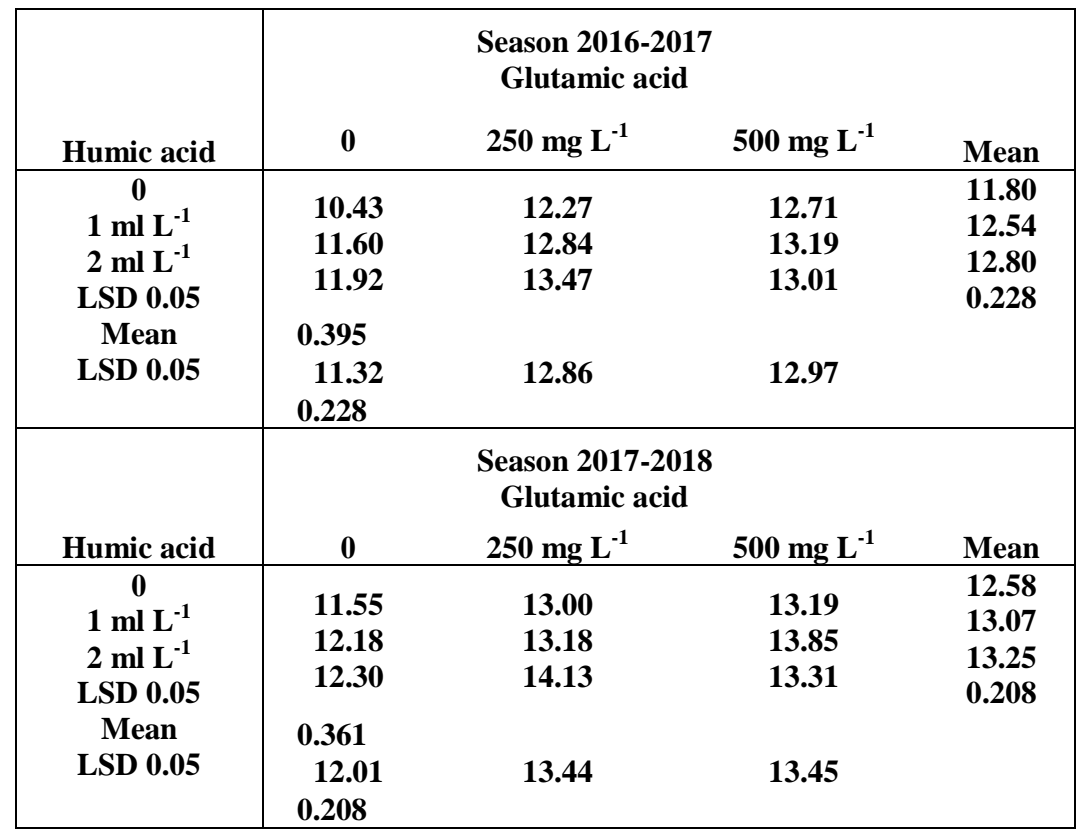

From obtained data in this study, foliar spraying wheat plants with humic acid and glutamic acid at tillering and flowering stages with $2 \mathrm{ml} \mathrm{L}^{-1}$ concentration from humic acid and $250 \mathrm{mg} \mathrm{L}^{-1}$ concentration from glutamic acid, because most of the studies traits significantly increased with spray by these acids at these concentrations.

\section{REFERENCES}

1. Abd-allah, M.M.Sh., H.M.S. EL-Bssiouny, B.A. Bakry and M.Sh. Sadak. 2015. Effect of arbuscular mycorrhiza and glutamic acid on growth, yield .some chemical composition and nutritional quality of wheat plant grown in newly reclaimed sandy soil .Rese. J.of Pharm., Biolo and Chemi.Sci.6 (3):1038-1054

2. Abdel-Aziz and L.K.Balbaa.2007.Influence of tyrosine and zinc on growth, flowering and chemical constituents of Salvia farinacea plants .J.of Applied Sci.Res.3 (11):1479-1489

3. Abdel-Aziz, N.G., A.A. Mazher and M.M. Farahat. 2010. Response of vegetative growth and chemical constituents of Thuja orientals L.to foliar application of different amino acid at Nubaria .J.Am.Sci.6 (3):295-303

4. AL-Curtini,A.A.S. and S.H.M.AL-Tai.2011. Effect of bio fertilizer with macorazia glomis mosseae and organic fertilizer with humic acid and chemical fertilizer on Zea mays .L some plant growth traits its grown in gypsum soil. Proceedings of the fifth Scientific Conference of the collage of Agriculture, Univ. Tikrit .26 27.548-555

5. AL-Karawi, H.N.R. and W.A.ALRawi.2016.Effect of foliar application of organic extract and hamic acid application on strawberry production .Iraqi, J. Agri. Sci.47 (3):749-756.

6. AL-Qaisi, W.A., E.H.H.AL-Haeanee, and R. W. M. A. Bshei .2016.Effect of citric acid and glutamic acid on growth and yield wheat plant Triticum aesrivum L.J.Mustan.Sci.27(5):45-51

7. Cenellas,L.P.,F.L.Olivares,A.L.OkorokovaFacanha and A.R.Facanha .2002. Humic acids isolated from earthworm compost enhance root elongation, lateral root emergence and plasma membrane H-ATPase activity in maize roots .Plant Physio.130:1951-1957

8. Chen,Y., M.Nobili and T.Aviad .2004. Stimulatory Effect of Humic Substances on Plant Growth .In:Magdoft F.,Ray R.(eds): Soil Organic Matter in Sustainable Agriculture .CRC Press, Washington

9. Edrees, M.H. 2009.Plant Pysiology. Encyclopedia of the plant. Suzan Mubarak Scientific Exploration Center in Qario. Egypt. www.smsec.com.

10. Gadimov, A.G., R. Shahryari and A.G. Garayeva .2009. Aperspective on humic substances as natural technological products with miraculous biological effect on crops. Transaction of the Institute of Microbiology of 
Azerbaijan National Academy of Sciences (7):118-126

11. Glawischning, E., A. Tomas, W. Eisenreich, P. Spiteller, A. Bacher, and A.Gierl. 2000. Auxin biosynthesis in maize kernels .Plant Physiol.12 (3):1109-1120

12. Hunt, R. 1982. Plant Growth Curves: The functional Approach to Plant Growth Analysis. London, Edward Arnold. pp: 284

13. Jaddoa, K.A. and H. M. Salih. 2013. Fertilization of Wheat crop .Ministry of Agriculture .Heuristic prospectus .pp.12

14. Jain, V.K. 2011. Fundamentals of Plant Physiology. S.Chand and Company LTD. Ram Nagar,New Delhi,India: pp:348.

15. Kauser, A.M.and F.Azam.1985. Effect of humic act on corn seedling growth .Enviro. and Expert mental Bota.25:245-252

16. Khan, R.U.,A.Rashid ,M.S.Khan and E.Ozturk.2010.Impact of humic acid and chemical fertilizer application on growth and grain yield of rainfed wheat Triticum aestivum L. Pakistan .J.Agric .Res.23(3-4) :113-121

17. Mazher, A.M., M.Sahar, S.Zaghloul, A. Mahmoud, and H.S.Siam.2011. Stimulatory effect of kinetin, ascorbic acid and glutamic acid on growth and chemical constituents of Cdiaeum variegtum L. plants. Am-Euras. J. Agric .and Environ.Sci.10 (3):318-323

18. Omer, E.A., H.A.H. Said- ALAhi, A.G. EL Gendy, Kh. A. Shaban, and M.S. Hussein.2013. Effect of amino acids application on production, volatile oil and chemical composition of chamomile cultivated in saline soil at Sinai.J.of Appl. Sci.Res. 9(4) 3006-3021

19. Pettit, and E. Robert .2003.Emeritus Associate Professor Texas A\&M University,Organic Matter,Humus,Humates Humic acid, Fulvic acid and Humin:Their Importance in Soil Fertility

20. Robertson, M.J and F. Giunta.1994. Responses of spring wheat exposed to preanthesis water stress. Aust. J. Agri. Res. 45:1935
21. Saburi, M., M. R.H.S. Hadi and M.T.Darzi.2014. Effect of amino acids and nitrogen fixing bacteria on quantitative yield and essential oil content of basil ( Ocimum basilicum) .Agric .Sci. Dev. 3(8):265-268

22. Sadek, M.Sh. A. A. Abd EL-Monem, H.M.S. EL-Bassiouny, and N. M. Badr. 2012. Physiological response of sunflower Helianthus annuus L. to exogenous arginine and putrescine treatments under salinity stress .J.of Appl.Sci.Res.8 (10):4943-4957

23. Samarat, S. and M. Malakoti. 2005. Necessity of produce and utilization of organic acids for increase of quality and quantity of agricultural products. Sana publisher. Tehran. In Persian with English Summary

24. Schroder, M., N. Giermann and R. Zrenner. 2005. Functional analysis of the pyrimidine de novo synthesis pathway in Solanaceous species .Plant Physiol. 138:19261938

25. Steeve, B. 2003. Modifying Plant Growth Regulators .Carolina Biological life Science. pp: 1-3.

26. Tufail, M.,K. Nawaz and M.Usman.2014. Impact of humic acid on morphology and yield of wheat Triticum aestivum L. World Appl.Sci.J.30 (4):475-480

27. Vaughan, D.M and R.E. Malcolm. 1979. Effect of humic acid on invertase synthesis in roots of plants. Soil Biol.and Bioch. (11):247252

28. Verma, S.K. and M. Verma. 2008. Atex Book of Plant Physiology, Biochemistry and Biotechnology $10^{\text {th }}$ ed. S. Chand and Company LTD. Ram Nagar, New Delhi, India: pp:194196

29. Zadoks, J.C., T.T.Change, and C.F. Knozak. 1974. Adecimal code for growth stages of cereals. Weed Res. 14:415-421

30. Zeboon, N.H. 2018. Response of growth and yield of Zea May for foliar spraying with humic acid .Int.J.of Agri. and Stat.Sci.14 (1):153-157. 